\title{
KECEMASAN TERKAIT ALAT/UNIT DIALISA PADA PASIEN GGK DI RSPAD GATOT SOEBROTO
}

\section{JAKARTA}

\author{
Chandra Tri Wahyudi
}

Universitas Pembangunan Nasional "Veteran", Jakarta 12450, Indonesia

E-mail: ik_ziek@yahoo.com

\begin{abstract}
Abstrak
Untuk mengobati satu pasien dengan GGK, kami menggunakan frekuensi hemodialisa yang bervariasi tergantung pada kerusakan ginjal mereka, yaitu empat sampai lima jam dalam dua sampai tiga kali seminggu. Jenis pengobatan ini dapat menyebabkan stressor bagi pasien. Tujuan dari penelitian ini adalah untuk mengidentifikasi Hubungan lama Tingkat Dengan kekhawatiran laju hemodialisis terkait Peralatan / Dyalisis Satuan Pada Pasien GGK. Desain penelitian deskriptif digunakan analisis dengan pendekatan cross sectional. Populasi dalam penelitian ini adalah seluruh pasien GGK yang menjalani haemodialisa di unit haemodialisa RSPAD. Sampel representatif berjumlah 131 responden. Hasil Dari hasil uji statistic didapatkan nilai P Value $=0,004$ berarti $\mathrm{P}$ Value $<0,05$, sehingga terdapat hubungan yang bermakna antara lama menjalani hemodialisa dengan tingkat kecemasan klien terkait alat/unit dyalisis pada klien gagal ginjal di RSPAD Gatot Soebroto Jakarta.
\end{abstract}

Kata kunci: Lama menjalani Haemodialisa, tingkat kecemasan.

\section{ABSTRACT}

To treat a patient with $C R F$, we use hemodialysis frequency that varies depending on the damage to their kidneys, which is four to five hours in two to three times a week. This type of treatment can cause a stressor for patients. The aim of this study is to identify correlation between long time Level With hemodialysis rate concerns related Equipment / Dyalisis Unit In CRF patients. The study design used descriptive analysis with cross sectional approach. The population in this study were all patients who underwent Haemodialisa CRF in unit Haemodialisa Army Hospital. A representative sample amounted to 131 respondents. The results of the statistical test was obtained value $P$ Value $=0.004$ mean $P$ Value $<0.05$, so there is a significant correlation between long period of patient undergoing haemodialysa with the level of client anxiety associated tool / unit dyalisis on client renal failure at Gatot Subroto Army Hospital in Jakarta.

Key Words: Long period of Haemodialisa, the level of anxiety

\section{Pendahuluan}

Ginjal merupakan salah satu organ

tubuh yang mempunyai fungsi utama mempertahankan homeostatis dalam tubuh sehingga terdapat keseimbangan optimal untuk kelangsungan hidup sel.
Ginjal juga merupakan organ yang mengatur lingkungan kimia internal tubuh secara akurat, dan diperlukan untuk mempertahankan kehidupan (Brunner \& suddarth, 2001, dalam Suzzane, 2002). Fungsi ginjal adalah 
elektrolit serta asam basa dengan cara menyaring darah melalui ginjal. Elektrolit dan non elektrolit juga mengekresikan kelebihannya sebagai kemih( urine). Ginjal mengeluarkan sampah metabolisme seperti urea, kreatinin, asam urat dan zat kimia asing. Kegagalan ginjal dalam melakukan fungsi-fungsi vital ini menimbulkan keadaan yang disebut uremia atau penyakit ginjal stadium akhir/ terminal (Price\&Wilson, 2006).

Gagal ginjal kronis (GGK) di dunia sudah mencapai 26 juta orang, dan 20 juta diantaranya sudah masuk kedalam tahap akhir atau terminal. www.antiloans.org, 2009). Di negara maju, angka penderita gangguan ginjal tergolong cukup tinggi. Di Amerika Serikat misalnya, angka kejadian gagal ginjal meningkat tajam dalam 10 tahun. Pada 1990, terjadi 166 ribu kasus GGK dan pada 2000 menjadi 372 ribu kasus. Angka tersebut diperkirakan terus naik. Pada 2010, jumlahnya diestimasi lebih dari 650 ribu. Selain data tersebut, 6 juta-20 juta individu di AS diperkirakan mengalami GGK fase awal.( www.antiloans.org, 2009). Hal yang sama terjadi di Jepang. Di Negeri Sakura itu, pada akhir 1996, ada 167 pengganti ginjal.

Menurut data 2000, terjadi peningkatan menjadi lebih dari 200 ribu penderita. Berkat fasilitas yang tersedia dan berkat kepedulian pemerintah yang sangat tinggi, usia harapan hidup pasien GGK di Jepang bisa bertahan hingga bertahuntahun.Bahkan, dalam beberapa kasus, pasien bisa bertahan hingga umur lebih dari 80 tahun. Angka kematian akibat GGK pun bisa ditekan menjadi 10 per 1.000 penderita. Hal tersebut sangat tidak mengejutkan karena para penderita di Jepang mendapatkan pelayanan cuci darah yang baik serta memadai. Pada tahun 2007 jumlah pasien GGK di Indonesia mencapai 2148 orang. Kemudian mengalami peningkatan pada tahun 2008 yaitu sebesar 2260. Hal ini dikarenakan kurangnya kesadaran masyarakat terhadap deteksi dini penyakit GGK tersebut. (www.republika.co.id,2009).

Kondisi yang paling parah pada gagal ginjal dengan karakteristik nilai bersihan kreatinin (CCT) 5-10 $\mathrm{ml} /$ menit, laju filtrasi (GFR) $10 \%$ dari keadaan normal, ureum darah (BUN) meningkat, isoosmosis dengan berat jenis yang tetap sebesar 1,010, ginjal tidak dapat lagi mempertahankan 
Wilson, 2006). Berbagai upaya dilakukan untuk mengatasi masalah GGK seperti pola makan, transplantasi ginjal dan salah satunya dengan hemodialisis.

Hemodialisis adalah salah satu upaya mengatasi gagal ginjal kronis, ini merupakan terapi pengganti utama pada pasien GGK yang berlangsung seumur hidup. Dikatakan pengganti karena menggantikan ginjal yang sudah tidak berfungsi lagi. Ginjal buatan hanya dapat menggantikan fungsi ekskresi dari zat- zat Toksik uremia yang tidak berguna lagi, bila tidak dikeluarkan dari tubuh dapat menurunkan kualitas hidup atau meninggal. Dan cara lain untuk mengeluarkan produk limbah dan toksin dalam tubuh adalah hemodialisa. Data registrasi pada tahun 2009 diruang Hemodialisa RSPAD Gatot Soebroto Jakarta pada bulan Januari: 147 orang, Februari: 164 orang, Maret: 165 orang. Terlihat terjadi peningkatan jumlah kunjungan pasien GGK. Sedangkan pada bulan April terjadi penurunan kunjungan yaitu 131 orang. Pasien GGK menjalani hemodialisis secara kontinyu dan menetap untuk mempertahankan kelangsungan hidupnya. Frekuensi dilakukan pada kerusakan ginjalnya.

Hemodialisis dilakukan empat sampai lima jam dalam dua sampai tiga kali perminggu. Hal ini dapat menjadi stressor bagi pasien karena dapat dikategorikan ancaman terhadap diri pasien, yang dapat menimbulkan ketidaknyamanan berhubungan dengan penusukan alat dialisa, ketidakpastian berapa lama dialysis diperlukan (Hudak \& Gallo, 1996). Menurut hasil penelitian Safitri.(2007): Dalam penelitian yang berjudul Gambaran Kenyamanan Klien Gagal Ginjal Kronik Pada Saat Diberikan Terapi Hemodialisa R.S Kepolisian Pusat Raden Said Soekanto Kramat Jati. Didapatkan hasil dari 57,5\% responden mengatakan nyaman secara fisik, psiko spiritual, social dan lingkungan pada saat diberikan terapi hemodialisa dan sebanyak 42,5\% mengatakan tidak nyaman secara fisik, psikospiritual, social dan lingkungan. Jadi lebih banyak responden yang menagatakan nyaman pada saat diberikan terapi hemodialisa.

Klien yang menjalani hemodialisis mengalami depresi, ketakutan dan kecemasan. Tingkat kecemasan klien hemodialisis dipengaruhi oleh beberapa factor fisiologis dan biologis, baik dari dalam pasien maupun dari luar pasien, 
hemodialisis, social ekonomi, usia pasien, kondisi pasien. Lama dan frekuensi menjalani hemodialisa timbul karena ancaman diri pasien sehingga menimbulkan respon psikologis dan prilaku pasien yang dapat diamati, sedangkan ancaman diri pada pasien hemodialisis dapat bersumber dari respon manusia (perawat), interaksi manusia dan lingkungan yang terpapar oleh alat yang digunakan (Lazarus \& Folkman, 1984, dalam Welch,2001).

Pasien yang mengalami dialysis jangka panjang maka akan merasa khawatir atas kondisi sakitnya yang tidak dapat diramalkan dan berefek terhadap gaya hidup. (Brunner \& Suddarth,2001, dalam Suzzane, 2002).

Menurut hasil penelitian Sunardi.(2001): Dalam penelitian yang berjudul tentang hubungan lama menjalani hemodialisa dengan tingkat kecemasan terkait alat/unit dialisa pada pasien GGK di RSUPN Dr.cipto Mangunkusumo didapatkan hasil nilai “ r" sebesar 0,22.

Hasil ini menunjukkan korelasi/hubungan sangat rendah antara lamanya menjalani hemodialisa terhadap tingkat kecemasan terkait alat/unit dialisa yang berarti bahwa rendah antara dua variable tsb. Bila nilai tersebut dikuadratkan menjadi 0,0484 , yang berarti terdapat hubungan positif linier sebesar $4,8 \%$ terhadap keduanya. Jadi dapat diartikan bila semakin lama menjalan hemodialisa terjadi peningkatan kecemasan pada klien GGK dilakukan hemodialisa sebesar $4,8 \%$ atau sebaliknya.

Berdasarkan wawancara dan observasi pada 2 pasien GGK yang menjalani hemodialisa di unit Hemodialisa RSPAD Gatot Soebroto, pasien yang baru menjalani hemodialisa mengatakan merasa cemas akan penusukan jarum dialisa, melihat darah yang ada diselang kateter dialisa dan suara alarm unit dialisa yang berbunyi.

Kemudian pada pasien yang sudah lama menjalani hemodialisa mengatakan merasa cemas akan penusukan jarum dialisa dan juga mengatakan sampai kapan penyakitnya dapat diatasi.

Dari penguraian diatas berdasarkan wawancara dan observasi pada pasien GGK yang menjalani Hemodialisa serta penelitian terkait diatas, peneliti ingin meneliti Hubungan Lama dan Frekuensi Menjalani Hemodialisis dengan Tingkat Kecemasan Terkait Alat Dialisa Di RSPAD Gatot Soebroto Jakarta. 
Penelitian ini menggunakan metode deskriptif analitik, yang mana untuk mengidentifikasi gambaran variable yang diteliti dan juga mencari hubungan antara variable yang diteliti. Metode pendekatan yang digunakan adalah cross sectional yaitu objek penelitian diukur dan dikumpulkan secara simultan, sesaat atau satu kali saja dalam satu kali waktu (dalam waktu yang bersamaan).

Populasi dalam penelitian ini adalah pasien gagal ginjal kronik yang menjalani hemodialisa di unit hemodialisa Rumah Sakit Pusat Angkatan Darat Gatot Subroto Jakarta sebanyak 131 Responden .

Dalam pengambilan sample dilakukan dengan cara non probability sampling yaitu sampling jenuh. Sampling jenuh merupakan penentuan sample bila semua anggota populasi digunakan sebagai sampel. Artinya seluruh pasien GGK yang menjalani Hemodialisa di unit Hemodialisa Rumah Sakit Pusat Angkatan Darat Gatot Soebroto Jakarta Sebanyak 131 responden. Tehnik pengambilan sampel menggunakan accidental sampling yaitu dimana dalam pengambilan sampel tidak kebetulan dengan kriteria sampel sebagai berikut:

Kriteria Inklusi (diizinkan):

a. Pasien yang menjalani terapi hemodialisa

b. Bisa baca tulis

c. Sehat mental

d. Bersedia mengisi atau berpartisipasi dalam mengisi kuisioner.

Kriteria Eklusi (tidak diizinkan):

a. Pasien yang tidak menjalani hemodialisa

b. Tidak bisa baca tulis

c. Tidak sehat mental

Pengumpulan data dilakukan secara primer yaitu dengan memberikan kuisioner kepada responden langsung dan beberapa responden dengan wawancara, dengan menggunakan pertanyaan struktur yang telah disediakan. Selain itu pengumpulan data dilakukan secara sekunder yaitu data didapatkan dari rumah sakit yang akan dipakai untuk penelitian tersebut yaitu di RSPAD Gatot Soebroto.

Sebelumnya peneliti terlebih dahulu memperkenalkan diri, lalu secara singkat menjelaskan maksud dan tujuan penelitian, dan akhirnya menanyakan kesediaan responden untuk diwawancarai. 
menunjukan alat ukur ini benarbenar mampu mengukur apa yang seharusnya diukur menurut situasi dan kondisi tertentu (Notoadmojo, 2005).

2. Reliabilitas adalah indeks yang menunjukkan sejauh mana suatu alat pengukur dapat dipercaya dan dapat diandalkan. Untuk menguji validitas dan reliabilitas alat, peneliti melakukan uji coba kuesioner. Tujuannya adalah untuk mengetahui sejauh mana ketepatan alat ukur tersebut dalam mengukur hasil, waktu pelaksanaannya yaitu pada bulan Mei 2009. Untuk menguji Reliabilitas adalah dengan menggunakan metode Cronbach's Alpha ( $\alpha)$ merupakan tehnik pengujian reliabilitas suatu tes atau angket yang paling sering digunakan oleh karena dapat digunakan pada tes atau angketangket jawaban atau tanggapan berupa pilihan, pilihannya dapat terdiri dari dua pilihan atau lebih.

Standar yang digunakan dalam menentukan reliabel atau tidaknya suatu instrument penelitian umumnya adalah perbandingan antara nilai $\mathrm{r}$ hitung diwakili dengan nilai alpha dengan $r$ tabel. Nilai $r$ tabel dilihat pada tabel $\mathrm{r}$ dengan menggunakan $\mathrm{df}=\mathrm{n}-2$ pada taraf kepercayaan 0,95 atau tingkat singnifikan/ kemaknaan 0,05. Tingkat
Chronback diukur berdasarkan skala Alpha 0 sampai dengan 1, apabila skala Alpha tersebut dikelompokkan ke dalam 5 kelas dengan range yang sama, maka ukuran kemantapan Alpha dapat dipresentasikan seperti tabel berikut Arikunto (2006):

\section{Hasil Penelitian}
A. Analisis Deskriptif (Univariat)
1. Karakteristik Responden

\section{a. Umur}

Tabel 1. Distribusi Frekuensi Kategori Umur Responden di RSPAD Gatot Soebroto Jakarta Tahun 2009

\begin{tabular}{|c|c|c|}
\hline Umur & Frekuensi & Persen (\%) \\
\hline $\begin{array}{c}<40 \\
\text { Tahun }\end{array}$ & 28 & 21,4 \\
\hline $\begin{array}{c}\geq 40 \\
\text { Tahun }\end{array}$ & 103 & 78,6 \\
\hline Total & 131 & 100 \\
\hline
\end{tabular}

Berdasarkan tabel diatas dapat dilihat bahwa responden dengan usia $<40$ tahun sebanyak 28 responden $(21,4 \%)$ dan responden dengan usia $\geq 40$ tahun sebanyak 103 responden $(78,6 \%)$.

\section{b. Jenis Kelamin}


Kelamin Responden di RSPAD Gatot

Soebroto Jakarta Tahun 2009

\begin{tabular}{|c|c|c|}
\hline $\begin{array}{c}\text { Jenis } \\
\text { Kelamin }\end{array}$ & Frekuensi & Persen (\%) \\
\hline Laki-laki & 87 & 66,4 \\
\hline Perempuan & 44 & 33,6 \\
\hline Total & 131 & 100 \\
\hline
\end{tabular}

Dari tabel tersebut diatas berdasarkan jenis kelamin responden dapat dilihat 87 responden $(66,4 \%)$ berjenis kelamin lakilaki sedangkan 44 responden $(33,6 \%)$ berjenis kelamin perempuan.

\section{c. Pendidikan}

Tabel 3. Distribusi Frekuensi Pendidikan Responden di RSPAD Gatot Soebroto Jakarta Tahun 2009

\begin{tabular}{|l|c|c|}
\hline Pendidikan & Frekuensi & Persen (\%) \\
\hline Tinggi & 119 & 90,8 \\
\hline Rendah & 12 & 9,2 \\
\hline Total & 131 & 100 \\
\hline
\end{tabular}

Dari tabel tersebut diatas berdasarkan pendidikan responden dapat dilihat 119 responden $(90,8 \%)$ memiliki tingkat pendidikan tinggi dan 12 responden $(9,2 \%)$ memiliki tingkat pendidikan rendah.

\section{d. Pekerjaan}

Responden di RSPAD Gatot Soebroto Jakarta Tahun 2009

\begin{tabular}{|l|c|c|}
\hline \multicolumn{1}{|c|}{ Pekerjaan } & Frekuensi & Persen (\%) \\
\hline PNS/TNI/Polri & 84 & 64,1 \\
\hline $\begin{array}{l}\text { Karyawan } \\
\text { Swasta }\end{array}$ & 12 & 9,2 \\
\hline Wiraswasta & 2 & 1,5 \\
\hline Lainnya & 33 & 25,2 \\
\hline \multicolumn{1}{|c|}{ Total } & 131 & 100 \\
\hline
\end{tabular}

Dari tabel tersebut diatas berdasarkan pekerjaan responden dapat dilihat 84 responden $(64,1 \%) \quad \mathrm{PNS} / \mathrm{TNI} /$ Polri, 12 responden $(9,2 \%)$ karyawan swasta, 2 responden $(1,5 \%)$ wiraswasta dan lainnya 33 responden $(25,2 \%)$.

\section{e. Penghasilan}

Tabel 5. Distribusi Frekuensi Penghasilan Responden di RSPAD Gatot Soebroto Jakarta Tahun 2009

\begin{tabular}{|l|c|c|}
\hline Penghasilan & Frekuensi & Persen (\%) \\
\hline Tinggi & 82 & 62,6 \\
\hline Rendah & 49 & 37,4 \\
\hline Total & 131 & 100 \\
\hline
\end{tabular}

Dari tabel tersebut diatas berdasarkan pendidikan responden dapat dilihat 119 responden $(90,8 \%)$ memiliki penghasilan tinggi dan 49 responden $(62,6 \%)$ memiliki penghasilan rendah. 
Tabel 6. Distribusi Frekuensi Kategori

Lama Menjalani Hemodialisis di RSPAD

Gatot Soebroto Jakarta Tahun 2009

\begin{tabular}{|c|c|c|}
\hline $\begin{array}{c}\text { Lama } \\
\text { Hemodialisis }\end{array}$ & Frekuensi & Persen (\%) \\
\hline Baru & 62 & 47,3 \\
\hline Lama & 69 & 52,7 \\
\hline Total & 131 & 100 \\
\hline
\end{tabular}

Berdasarkan lama responden menjalani hemodialisis terlihat bahwa 69 responden $(52,7 \%)$ baru menjalani hemodialisis sedangkan 62 responden $(47,3 \%)$ sudah lama menjalani hemodialisis.

\section{B. Hasil Penelitian Bivariat}

Tabel 9. Analisis Hubungan Lama

Responden Menjalani Hemodialisis dengan Kecemsan Responden di RSPAD Gatot Soebroto Jakarta Tahun 2009

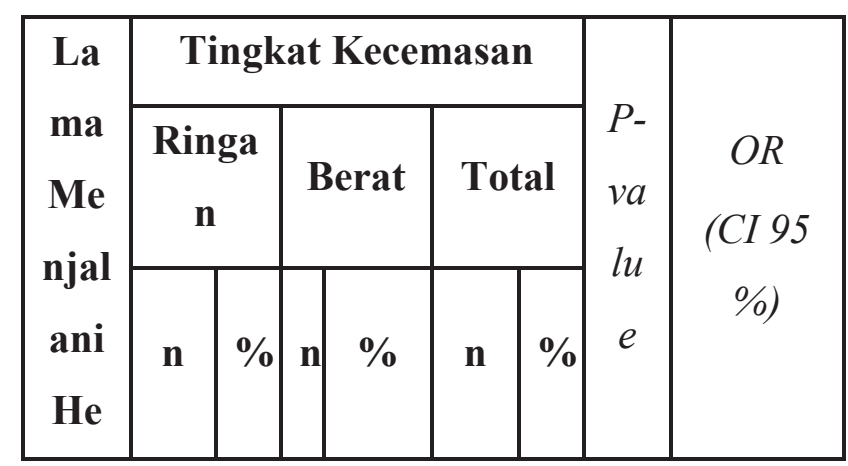

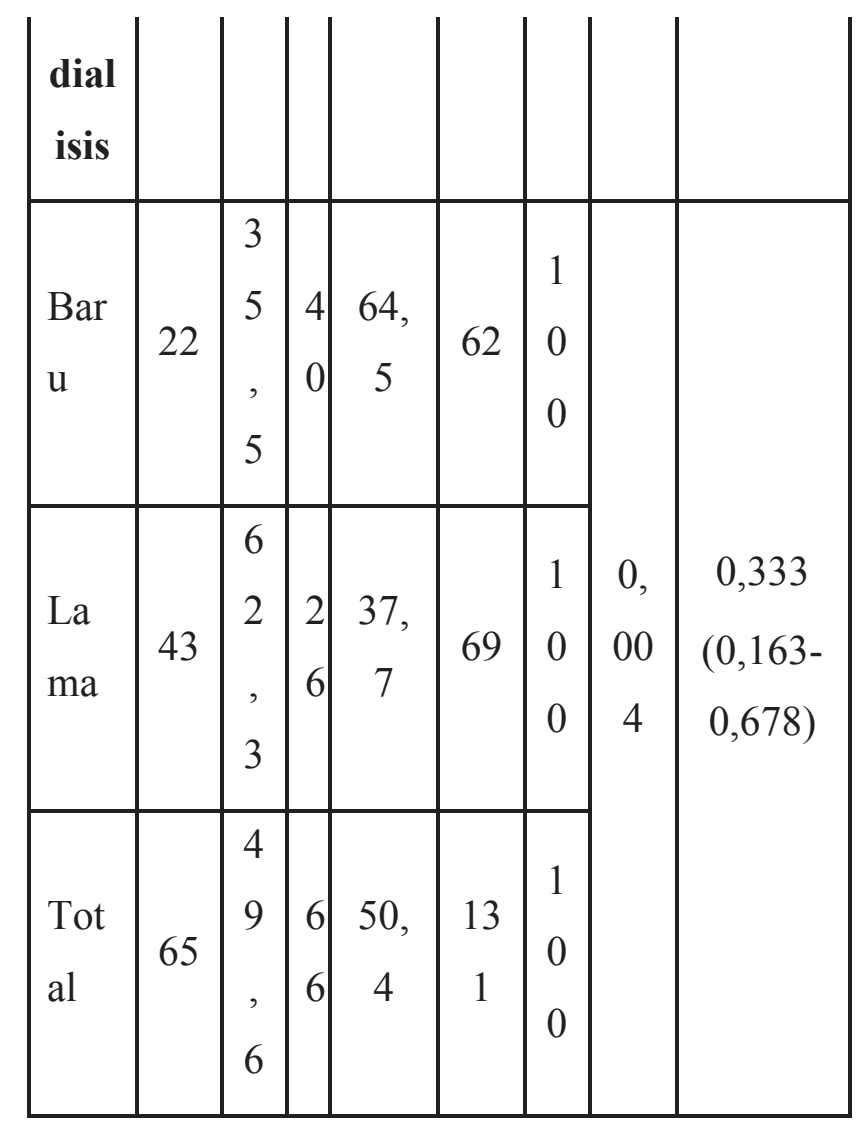

Berdasarkan tabel silang (cross tabulation) di atas dari 62 responden yang baru menjalani hemodialisis terlihat bahwa 22 responden $(35,5 \%)$ memiliki tingkat kecemasan ringan dan 40 responden $(64,5 \%)$ memiliki tingkat kecemasan berat. Sedangkan dari 69 responden yang telah lama menjalani hemodialisis terlihat bahwa 43 responden $(62,3 \%)$ memiliki tingkat kecemasan ringan dan 26 responden $(37,7 \%)$ memiliki tingkat kecemasan berat. Hasil uji statistic didapatkan nilai $\mathrm{P}$ Value $=$ 0,004 berarti $\mathrm{P}$ Value $<0,05$, sehingga dapat disimpulkan terdapat hubungan yang bermakna antara lama menjalani hemodialisa dengan tingkat kecemasan klien terkait alat/unit dyalisis pada klien gagal ginjal di RSPAD Gatot Soebroto 
disimpulkan bahwa responden dengan yang baru menjalani hemodialisa 0,333 (CI: 0,163-0,678) kali memiliki tingkat kecemasan lebih berat dibandingkan dengan responden yang telah lama menjalani hemodialisis.

\section{Pembahasan}

\section{Hubungan Lama Menjalani Hemodialisis dengan Tingkat Kecemasan Responden}

Hasil penelitian yang dilakukan di unit hemodialisa RSPAD Gatot Soebroto Jakarta dari 62 responden yang baru menjalani hemodialisis terlihat bahwa 22 responden $(35,5 \%)$ memiliki tingkat kecemasan ringan dan 40 responden $(64,5 \%)$ memiliki tingkat kecemasan berat. Sedangkan dari 69 responden yang telah lama menjalani hemodialisis terlihat bahwa 43 responden $(62,3 \%)$ memiliki tingkat kecemasan ringan dan 26 responden (37,7\%) memiliki tingkat kecemasan berat.

Dari hasil uji statistic didapatkan nilai $\mathrm{P}$ Value $=0,004$ berarti $\mathrm{P}$ Value $<0,05$, sehingga dapat disimpulkan terdapat hubungan yang bermakna antara lama menjalani hemodialisis dengan tingkat kecemasan klien terkait alat/unit dyalisis pada klien gagal ginjal kronik di RSPAD Gatot Soebroto Jakarta. bahwa responden dengan yang baru menjalani hemodialisa 0,333 (CI: 0,1630,678) kali memiliki tingkat kecemasan lebih berat dibandingkan dengan responden yang telah lama menjalani hemodialisis.

Kecemasan adalah keadaan ketika individu/kelompok mengalami perasaan gelisah (penilaian atau opini) dan aktivasi system syaraf autonom dalam berespon terhadap ancaman yang tidak jelas, non spesifik. (Carpenito, 2006)

Kecemasan pasien gagal ginjal kronik berhubungan dengan lama klien menjalani hemodialisis, semakin lama klien menjalani hemodialisis maka klien tersebut akan dapat beradaptasi dengan alat/unit dialisa (Suliswati, 2005).

Pasien yang mengalami dialysis jangka panjang maka akan merasa khawatir atas kondisi sakitnya yang tidak dapat diramalkan dan berefek terhadap gaya hidup. (Brunner \& Suddarth,2001)

Berdasarkan hasil yang didapat oleh peneliti bahwa responden yang telah lama menjalani hemodialisa cenderung memiliki tingkat kecemasan lebih ringan dibandingkan dengan responden yang baru menjalani hemodialisis hal ini disebabkan karena dengan lamanya seseorang menjalani hemodialisa maka seseorang akan lebih adaptif dengan alat/unit dyalisis. 
penelitian yang dilakukan oleh Sunardi (2001) tentang lama menjalani hemodialisa dengan tingkat kecemasan didapatkan nilai $r$ sebesar 0,22 hasil ini menunjukkan korelasi sangat rendah antara lama menjalani hemodialisis dengan kecemasan tingkat kecemasan.

\section{Kesimpulan}

Hasil penelitian ini dapat menjelaskan bahwa fenomena yang mampu dikaji dalam penelitian ini adalah variabel lama menjalani haemodialisa dan tingkat kecemasan pasien yang menjalani haemodialisa. Terdapat hubungan yang bermakna antara lama menjalani hemodialisa dengan tingkat kecemasan klien terkait alat/unit dyalisis pada klien gagal ginjal di RSPAD Gatot Soebroto Jakarta. Berdasarkan hasil penelitian, maka peneliti menyarankan agar Rumah Sakit dapat memodifikasi lingkungan sehingga tingkat kecemasan pada pasien yang menjalani haemodialisa dapat menurun.

\section{Daftar Pustaka}

Arikunto, Suharsimi.(2006). Prosedur Penelitian Suatu Pendekatan Praktek. Jakarta: Rineka Cipta.

Azis Alimul Hidayat.(2007). Riset Keperawatan Dan Teknik Penulisan Ilmiah.Edisi II. Jakarta: Salemba Medika
Saku Diagnosis Keperawatan. Edisi X. Jakarta: EGC

Desak Putu Jayanthi .(2008). "hubungan stress dan mekanisme koping dengan dukungan social keluarga dalam merawat pasien gagal ginjal kronik diunit Hemodialisa RSPAD Gatot Soebroto"

Guyton, Hall .(2007). Fisiologi Kedokteran. Edisi XI. Jakarta: EGC

Hastono Sutanto Priyanto. (2001). Modul Analisis Data.Fakultas Kesehatan Masyarakat Universitas Indonesia: Jakarta

Hemodialysis. Available at: http://www.kidney.ca/english/profile.ht m. Date Accessed: mei 28, 2009.

http://www.republika.co.id/berita/36726/36 Ju ta_Warga_Dunia_Meninggal_GagalGinj al diakses pada tanggal 6 mei 2009)

Hudak \& Gallo.(1996). Keperawatan Kritis Pendekatan Holistik. Edisi VI, Volume 2.Jakarta: EGC

Laviana.(2002)." Hubungan antara Frekwensi Dzikir dan Doa dengan Tingkat kecemasan pada pasien gagal ginja kronik yang menjalani hemodialisis"

Nettina, Sandra M. (2001). Pedoman Praktik

Keperawatan. Jakarta: EGC

Notoadmojo, Soekidjo. (2005). Metodologi Penelitian Kesehatan. Jakarta : Rineka Cipta

Price, Sylvia Anderson. (2005). Patofisiologi: Konsep Klinis Proses-Proses Penyakit. Jakarta: EGC 
Gagal Ginjal Kronik yang Menjalani of Advanced Nursing)

Hemodialisis terhadap PerubahanCitra

Diri Diruang Hemodialisa RSUPN Dr.

Cipto Mangunkusumo Dan RS

Pelabuhan Jakarta"

Safitri. (2007). “Gambaran Kenyamanan Klien

Gagal Ginjal Kronik Pada Saat

Diberikan Terapi Hemodialisa R.S

Kepolisian Pusat Raden Said Soekanto

Kramat Jati”

Scalon, Valeriec. (2006). Buku Ajar Anatomi

Dan Fisiologi. Edisi III. Jakarta: EGC.

Setiadi.(2007). Riset Keperawatan.Surabaya :

Graha Ilmu.

Smeltzer, Suzanne. (2002). Buku Ajar

Keperawatan Medikal Bedah Brunner

\& Suddarth. Edisi VIII Volume

2.EGC:Jakarta

Smeltzer, Suzanne.(1999). Text Book of

Medical Surgical Nursing.9 Th Edition, vol 2. Philadelphia: Lippimcott.

Stuart, Gail W. (2006). Buku Saku Keperawatan

Jiwa. Edisi V. Jakarta: EGC

Suliswati. (2005). Konsep Dasar Keperawatan

Kesehatan Jiwa. Jakarta: EGC

Sunardi.2001: “ hubungan lama menjalani hemodialisa dengan tingkat kecemasan terkait alat/unit dialisa pada pasien GGK Di RSUPN Dr.cipto Mangunkusumo"

Syahril Hasibuan (2005):" faktor-faktor yang menyebabkan kecemasan klien gagal ginjal kronik pada unit dialisa Rumah Sakit Kartika Medan”

Welch, J.L., \& Austin, J.K. (2001). Stressor, Coping and Depression in 